\title{
Studi Penempatan dan Kapasitas Pembangkit Tersebar terhadap Profil Tegangan dan Rugi Saluran pada Saluran Marapalam
}

\author{
Syukri Yunus* dan Imbang Ismail \\ Jurusan Teknik Elektro Fakultas Teknik Universitas Andalas \\ *Corresponding author, e-mail: syukri_yunus@ft.unand.ac.id
}

\begin{abstract}
Abstrak-Penelitian ini bertujuan untuk untuk mengurangi rugi daya dan meningkatkan profil tegangan berdasarkan penempatan dan kapasitas DG yang optimal di jaringan distribusi penyulang Marapalam. Metode yang digunakan adalah metode Sensitivity analisis dengan salah satu analisisnya adalah menggunakan Loss Sensitivity Factor (LSF) dan metode Voltage Sensitivity Index (VSI). Hasil kedua metode ini dibandingkan dengam metode trial and error. DG dapat mengurangi rugi daya pada saluran dan penempatan DG yang tepat untuk mendapatkan rugi daya yang minimal. ETAP 12.6 diaplikasikan untuk menghitung sensitivitas rugi daya, sensitivitas tegangan jaringan guna memperoleh penempatan DG yang optimal. Berdasarkan studi kasus jaringan distribusi penyulang marapalam, diperoleh lokasi optimal dari DG photovoltaic adalah pada bus 147B dengan injeksi daya sebesar $75 \%$ daya yang disalurkan ke saluran Marapalam. Penempatan ini mampu mengurangi rugi daya aktif dan reaktif dari $35,792 \mathrm{~kW}$ dan 57,363 kVar menjadi 8,159kW dan 13,079kVar. Sedangkan lokasi yang optimal dari DG turbin angin adalah pada bus 293T dengan penetrasi $45 \%$ dari daya yang disalurkan ke saluran Marapalam mampu mengurangi rugi daya aktif dan reaktif menjadi $24,89 \mathrm{~kW}$ dan $39,9 \mathrm{kVar}$.
\end{abstract}

Kata Kunci : Pembangkit Tersebar, rugi daya, analisa sensitivitas.

\begin{abstract}
This study aims to reduce the power loss and increase the voltage profile based on optimal placement and DG capacity on feeder Marapalam. The applied methods are the Sensitivity analysis method with Loss Sensitivity Factor (LSF) and Voltage Sensitivity Index (VSI). The results of both methods are compared with trial and error method. DG can reduce power losses on the lines and DG placement must be appropriate to obtain minimal power loss. Using ETAP 12.6, the sensitivity of power losses and the sensitivity of network voltages of Marapalam distribution network are calculated. The optimal location on DG photovoltaic is on a 147B bus with a power injection of $75 \%$, able to reduce active and reactive power losses from $35,792 \mathrm{~kW}$ and $57,363 \mathrm{kV}$ ar to $8,159 \mathrm{~kW}$ and $13,079 \mathrm{kVar}$. While the optimal location on DG wind turbine is on bus $293 \mathrm{~T}$ with penetration of $45 \%$ of the power supplied to the Marapalam line, able to reduce the active and reactive power to $24,89 \mathrm{~kW}$ and $39,9 \mathrm{kV}$ ar.
\end{abstract}

Keywords : Distributed Generator power loss, sensitivity analysis

\section{Pendahuluan}

Energi listrik merupakan suatu bentuk energi yang sangat penting dalam kehidupan manusia pada zaman ini. Faktor pertumbuhan penduduk yang terus meningkat membawa banyak pengaruh dalam kehidupan, khususnya dalam bidang energi listrik. Hal ini menyebabkan terjadinya peningkatan kebutuhan kapasitas energi setiap tahun. Keadaan ini tidak didukung oleh ketersediaan cadangan energi di Indonesia mengingat sebagian besar pembangkit di Indonesia masih banyak menggunakan bahan bakar fosil. Solusi terkait permasalahan tersebut adalah diversifikasi energi, salah satunya ialah mengembangkan energi terbarukan. Di feeder
Marapalam, pada beberapa tahun terakhir telah terjadi perkembangan yang cukup pesat dalam hal permintaan energi listrik karena meningkatnya aktivitas perindustrian dan juga perdagangan.

GIS (Gas Insulated Switchgear) Simpang Haru merupakan gardu induk yang menyuplai daya ke feeder Marapalam dengan menggunakan sistem jaringan radial $20 \mathrm{kV}$. Semakin bertambahnya permintaan energi listrik pada feeder marapalam maka semakin besar juga beban yang ditanggung oleh GIS Simpang Haru. Apabila beban yang dilayani oleh GIS semakin banyak dan jaraknya jauh dari gardu induk maka hal ini dapat menyebabkan rugi-rugi daya dan penurunan profil tegangan. 
Untuk mengatasi permasalahan tersebut, maka perlu suatu solusi terkait beban listrik pada GIS. Salah satu caranya adalah dengan mengaplikasikan pembangkit tersebar pada feeder Marapalam. Hal ini tentunya harus sesuai dengan potensi energi terbarukan yang ada di Marapalam.

Pemasangan pembangkit tersebar dalam jaringan distribusi haruslah pada posisi yang optimal. Pemasangan kapasitas dan lokasi pembangkit tersebar yang tidak optimal pada jaringan distribusi akan menyebabkan rugi daya yang lebih besar dibandingkan pemasangan pada lokasi dan kapasitas optimalnya. Oleh sebab itu maka perlu dikaji suatu metode untuk menentukan lokasi dan kapasitas optimal dari pembangkit tersebar di jaringan distribusi [1].

Dengan mengaplikasikan optimasi penempatan dan kapasitas pembangkit tersebar pada feeder Marapalam diharapkan mampu mengurangi beban yang di pikul oleh GIS Simpang haru serta dapat mengurangi rugi-rugi daya pada sistem.

\section{Tinjauan Pustaka}

\subsection{Pembangkit Tersebar}

Pembangkit listrik tersebar (DG) adalah unit pembangkit kecil yang dekat dengan lokasi beban. DG dapat beroperasi secara terisolasi untuk daerah-daerah yang tidak terpasok oleh jaringan listrik PLN, namun dapat juga terintegrasikan ke dalam grid untuk memasok daya sistem tenaga listrik. [2]:

Beberapa keuntungan penggunaan DG adalah

a. Meningkatkan keandalan suplai daya ke pelanggan, jika mungkin, dapat mengurangi rugi saluran distribusi.

b. Meningkatkan profil tegangan, kualitas daya dan kestabilan tegangan.

c. Instalasi DG membutuhkan waktu yang singkat.

d. Beberapa teknologi DG ramah lingkungan (misalnya photovoltaic dan wind) dan cukup efisien seperti Combined Heat and Power (CHP) dan mikroturbin.

\subsection{Rugi Saluran Sistem Tenaga Listrik}

Daya listrik yang dikirim dari pembangkit listrik ke beban akan mengalami rugi saluran yang besarnya dapat dihitung menggunakan persamaan (1) $[4,5]$ :

$$
\Delta P=3 \times I^{2} \times R_{\text {efektif }}
$$

Dimana:

$$
\begin{array}{ll}
\Delta \mathrm{P} & =\text { Rugi-rugi saluran }(\mathrm{W}) \\
\mathrm{I} & =\text { Arus yang mengalir (Ampere) } \\
\mathrm{R}_{\text {efektif }} & =\text { Resistansi saluran efektif (Ohm) }
\end{array}
$$

Persentase rugi saluran dapat dihitung dengan persamaan (2):

$$
\% \text { Ploss }=\frac{P \text { Loss }}{P} \times 100 \%
$$

$$
\begin{array}{ll}
\text { Dimana: } & \\
\text { \%Ploss } & =\text { rugi }- \text { rugi saluran }(\%) \\
\text { Ploss } & =\text { rugi }- \text { rugi saluran }(\text { Watt }) \\
\mathrm{P} & =\text { daya yang disalurkan }(\text { Watt })
\end{array}
$$

\subsection{Rugi Saluran Setelah Penempatan DG}

Rugi saluran pada sistem distribusi lebih besar dibanding dengan sistem transmisi. Sekitar 70\% rugi daya pada system tenaga terjadi di jaringan distribusi dan hanya $30 \%$ terjadi pada sistem transmisi [3]. Rugi saluran akan meningkatnya seiring naiknya permintaan energi sehingga meningkatkan biaya produksi. Oleh karena itu, penting untuk menjaga rugi daya pada sistem distribusi seminimal mungkin untuk mengurangi biaya [2].

Rugi-rugi pada saluran distribusi adalah yang terdiri dari n saluran diberikan dengan :

$$
\mathrm{P}_{\mathrm{L}}=\sum_{\mathrm{i}=1}^{\mathrm{n}} \mathrm{I}_{\mathrm{i}}^{2} \mathrm{R}_{\mathrm{i}}
$$

Dimana, $\mathrm{P}_{\mathrm{L}}$ adalah total rugi daya aktif pada sistem, I dan $\mathrm{R}$ adalah arus dan resistansi saluran. Untuk system 3 fasa, rugi saluran ditunjukkan pada persamaan (4).

$$
\mathrm{P}_{\mathrm{L}}=3 \mathrm{I}^{2} \mathrm{R}
$$

Arus I dapat diperoleh dengan,

$$
\mathrm{I}_{\mathrm{G}}=\frac{\mathrm{P}_{\mathrm{G}}}{\sqrt{3} \mathrm{~V}_{\mathrm{G}} \cos \theta_{\mathrm{G}}}
$$

Dimana $\mathrm{I}_{\mathrm{G}}=\mathrm{I}$, dan $\mathrm{P}_{\mathrm{G}}$ adalah daya yang dibangkitkan $\mathrm{DG}, \mathrm{V}_{\mathrm{G}}$ adalah besar tegangan pada bus generator (terminal DG), dan $\cos \theta_{\mathrm{G}}$ adalah faktor daya. Sehingga didapatkan rumus rugi daya setelah penempatan DG adalah, 


$$
P_{L}=\frac{R\left(P_{G}\right)^{2}}{\left|V_{G}\right|^{2}\left(\cos \theta_{G}\right)^{2}}
$$

Dengan menganggap $\mathrm{R}, \mathrm{V}_{\mathrm{G}}$, dan $\cos \theta_{\mathrm{G}}$ konstan maka dapat disimpulkan bahwa semakin besar daya injeksi DG makin besar rugi saluran [2].

\subsection{Sensitivity Analysis}

Sensitivity analysis merupakan suatu metode yang digunakan untuk mencari lokasi yang paling sensitif untuk menempatkan DG.

\subsubsection{Loss Sensitivity Factor}

Salah satu jenis analisa sensitivitas adalah Loss Sensitivity Factor ( $L S F$ ) yang fungsinya untuk mencari suatu nilai faktor yang tujuannya mengurangi rugi daya. Keuntungan dari metode ini adalah dapat mencari lokasi rugi saluran yang terbesar pada bus secara cepat [6].

Gambar 1. memperlihatkan impedansi antara bus $\mathrm{i}$ dan $\mathrm{j}$ adalah impedansi saluran: $\mathrm{R}+\mathrm{j} X$, dan terhubung dengan beban $\mathrm{P}+\mathrm{jQ}$. Rugi saluran aktif pada saluran $\mathrm{ke}-\mathrm{k}$ adalah:

$$
P_{\text {loss }}=\left[I_{k}^{2}\right] \times R_{k}
$$

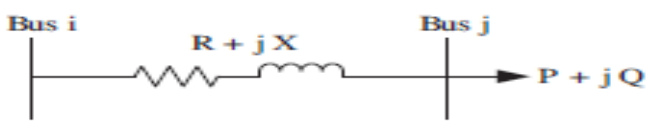

Gambar 1. Jaringan sederhana 2 bus

Dimana $\mathrm{I}_{\mathrm{k}}$ adalah arus pada saluran $\mathrm{k}$ dan $\mathrm{R}$ adalah resistansi saluran. $I_{k}$ dapat dihitung dengan:

$$
I_{k}=\left(\frac{P_{j}+j Q_{j}}{V_{j}}\right)^{*}=\frac{P_{j}+j Q_{j}}{V_{j}^{*}}
$$

Dimana $\mathrm{P}$ adalah beban daya aktif pada bus terima, $\mathrm{Q}$ adalah daya reaktif pada bus terima dan $\mathrm{V}$ adalah tegangan pada bus terima. Dengan mensubsitusikan persamaan (8) ke persamaan (7), didapatkan:

$$
P_{\text {loss }}=\frac{\left(P_{j}^{2}+Q_{j}^{2}\right) R_{k}}{V_{j}^{2}}
$$

Jadi, Loss Sensitivity Factor (LSF) adalah turunan dari rugi saluran dengan daya aktif.

$$
\frac{\partial P_{\text {loss }}}{\partial P}=\frac{\left(2 \times P_{j} \times R_{k}\right)}{\left(V_{j}\right)^{2}}
$$

Nilai LSF setiap bus diurutkan, dan yang terbesar akan menjadi prioritas penempatan DG.

\subsubsection{Voltage Sensitivity Index}

Metode lainnya dalam pencarian lokasi optimal adalah Voltage Sensitivity Index (VSI). Sensitivitas tegangan ini bertujuan untuk mencari performansi index tegangan dalam suatu sistem. Pada cara ini setiap bus di injeksikan daya sebesar $15 \%$ total beban maksimum feeder dengan meletakkan DG pada setiap bus. VSI dapat dihitung dengan persamaan (11). Ketika DG terhubung pada bus I, VSI pada bus I diberikan dengan $[6,7]$ :

$$
V S I_{i}=\sqrt{\frac{\sum_{k=1}^{n}\left(1-V_{k}\right)^{2}}{n}}
$$

Dimana $\mathrm{V}_{\mathrm{k}}$ adalah tegangan bus ke- $\mathrm{k}$ dan $\mathrm{n}$ adalah jumlah bus. Bus yang memiliki VSI paling kecil akan menjadi prioritas dalam penempatan DG. Hal ini karena semakin dekat nilai VSI dengan nol maka tegangan setiap bus pada sistem mendekati nilai referensi. Sehingga nilai VSI yang kecil performansi tegangannya lebih baik $[8,9]$.

\subsection{Trial and Error}

Trial and error adalah suatu metode dasar dalam pemecahan masalah. Metode ini dicirikan dengan pengulangan dan memvariasikan suatu variabel sampai solusi yang di inginkan tercapai [10]. Untuk penelitian ini trial and error digunakan untuk memperoleh penempatan DG yang optimal dengan cara setiap variasi kapasitas DG di injeksikan pada setiap bus hingga mendapatkan rugi saluran yang minimum. Nilai yang didapatkan pada metode ini sebagai bahan perbandingan dengan penempatan dengan metode LSF dan VSI.

Kelebihan metode ini adalah mampu menentukan penempatan DG yang benar-benar optimal. Namun kekurangannya adalah butuh waktu yang cukup lama dalam melakukannya untuk mendapatkan penempatan yang optimal [11]. 


\section{Metoda}

Langkah-langkah perhitungan yang dilakukan ditunjukkan oleh diagram alir pada gambar 2 . Langkah tersebut terdiri atas:

a. Pemodelan gambar single line diagram jaringan distribusi primer feeder marapalam dan menginput beberapa parameter analisisnya.

b. Melakukan simulasi aliran daya pada perangkat lunak ETAP 12.6 sebelum injeksi daya oleh pembangkit tersebar pada kondisi beban maksimum

c. Menganalisa profil tegangan dan rugi saluran sistem sebelum penempatan DG pada kondisi beban maksimum.

d. Menghitung nilai LSF (Loss Sensitivity Factor) dan VSI(Voltage Sensitivity Index) sebagai prioritas untuk pemilihan lokasi DG

e. Lokasi penempatan DG diambil dari prioritas nilai LSF dan VSI

f. Menentukan penempatan DG untuk penempatan pada bus yang terpilih.

g. Menentukan kapasitas DG pada bus yang terpilih dimana kapasitas yang dipilih yang memberikan rugi saluran paling kecil

h. Menganalisa profil tegangan dan rugi saluran setelah penempatan DG dilakukan.

\section{Hasil dan Pembahasan}

\subsection{Kondisi Awal Sistem}

Single line sistem yang dianalisa ditunjukkan pada Gambar 3. Dari hasil simulasi sebelum penempatan pembangkit tersebar, total daya beban adalah 5,395 MVA dengan distribusi daya aktif dan reaktif beban pada penyulang marapalam adalah 4,948 MW dan 2,150 MVar. Rugi saluran pada saluran sistem ini didapatkan sebesar 35,792 kW dan 57,363 kVar. Sedangkan tegangan terendah pada bus adalah $19,5 \mathrm{kV}$ atau 0.9793 pu. Untuk lebih jelasnya dapat dilihat pada Gambar 4.

Pada kondisi awal sistem sebelum penambahan pembangkit tersebar, nilai tegangan yang diterima bus-bus beban berbeda-beda. Perbedaan tegangan ini dipengaruhi oleh beban dan jarak bus tersebut. Semakin jauh jarak beban dari sumber maka impedansinya semakin besar sehingga menyebabkan nilai tegangan pada sisi penerima berkurang. Dari Gambar 4, nilai tegangan terendah terdapat pada bus 146B karena pada bus ini bebannya besar dan jaraknya jauh dari sumber.

Rugi saluran pada jaringan distribusi ini dipengaruhi oleh impedansi dan arus yang mengalir pada saluran tersebut. Impedansi dipengaruhi oleh panjang saluran dan arus dipengaruhi oleh beban pada sistem. Jika beban yang digunakan dalam suatu sistem besar maka arus yang mengalir juga besar.

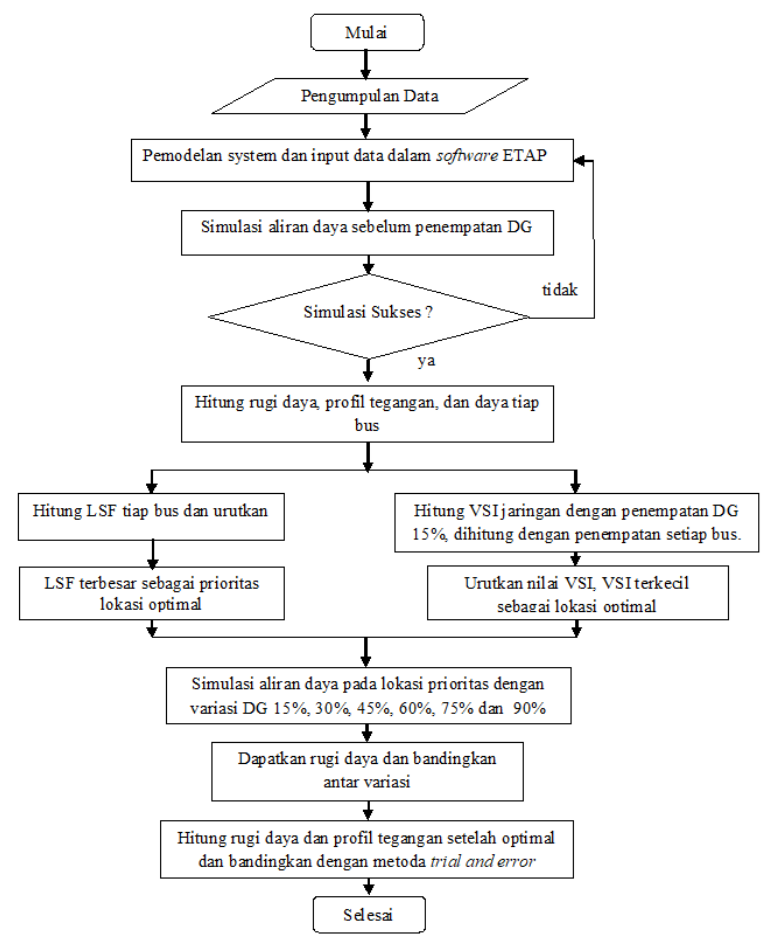

Gambar 2. Diagram alir penelitian

\subsection{Penempatan DG dengan Loss Sensitivity Factor}

Faktor sensitivitas rugi saluran dihitung di setiap bus pada pemodelan jaringan Marapalam. Nilai sensitivitas rugi saluran diurutkan dari yang terbesar ke yang terkecil. Nilai LSF yang terbesar menjadi prioritas penempatan Pembangkitan Tersebar (DG). Berdasarkan hasil simulasi dan perhitungan pada gambar 5, maka dipilih bus 293T sebagai kandidat penempatan DG karena bus yang paling sensitif terhadap rugi saluran Berdasarkan hasil simulasi, penentuan kapasitas optimum DG di bus 293T terhadap rugi saluran ditunjukkan pada gambar 6, Pada Gambar 6, dapat dianalisa bahwa rugi saluran pada sistem berkurang jika kapasitas DG semakin besar hingga mencapai kapasitas optimum, setelah itu 
nilai rugi salurannya meningkat kembali. Rugi saluran yang berkurang diakibatkan karena penetrasi daya dalam sistem menyebabkan berkurangnya daya suplai dari gardu induk sehingga arus yang mengalir dari gardu induk ketika melewati saluran distribusi berkurang akibatnya rugi saluran pada sistem juga berkurang. Sebaliknya untuk kapasitas DG diatas nilai optimum akan menyebabkan ekspor daya dari DG ke Grid yang akan menimbulkan rugi saluran.

\subsection{Penempatan DG dengan Voltage Sensitivity Index}

Nilai VSI dihitung untuk mengetahui indeks performansi tegangan pada suatu jaringan setelah di tempatkan DG pada setiap busnya. Nilai VSI dihitung pada setiap bus dengan penempatan DG $15 \%$ dari total beban feeder. Nilai VSI dihitung menggunakan rumus pada bagian 2 (Tinjauan Pustaka) di setiap bus.

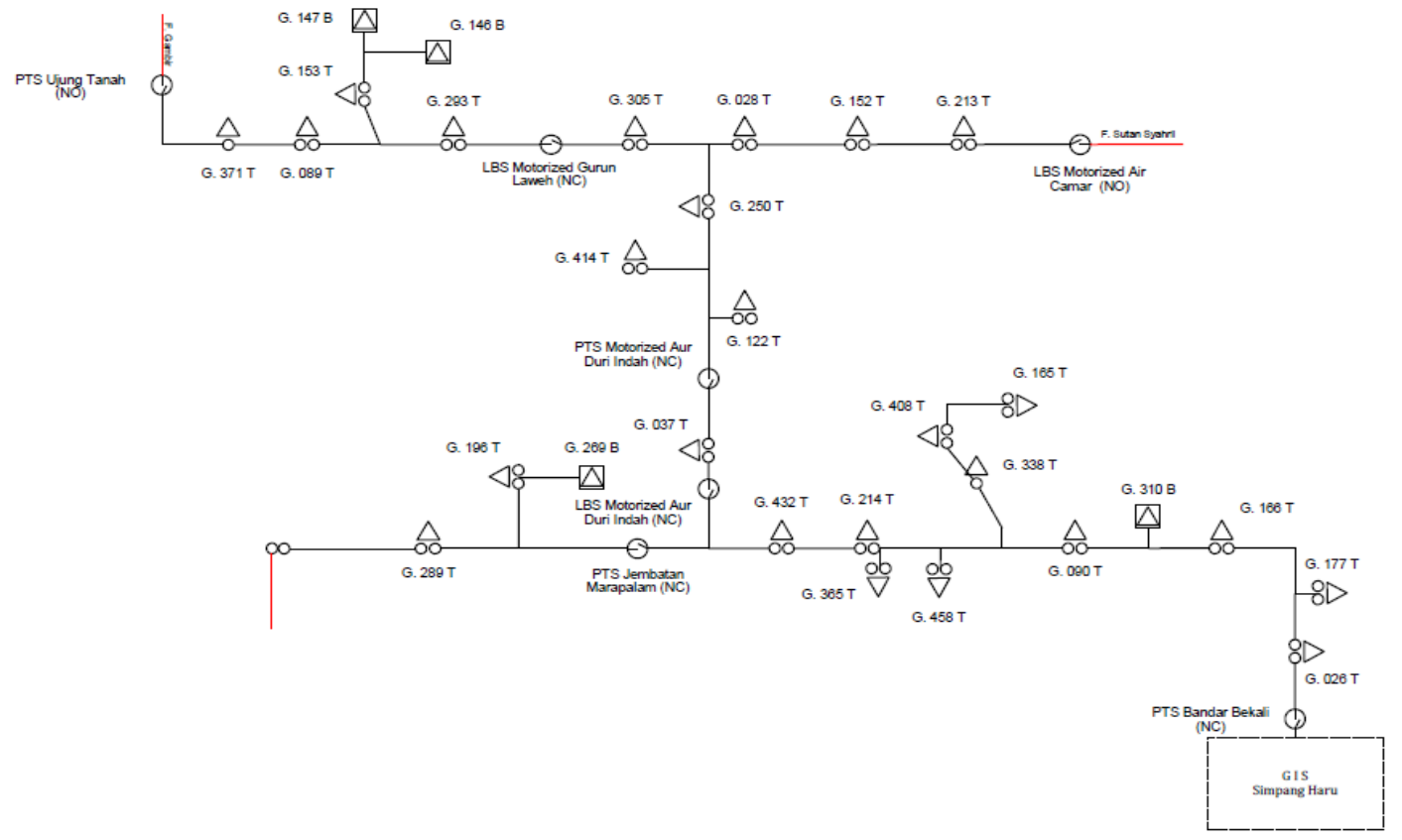

Gambar 3. Single line diagram feeder Marapalam

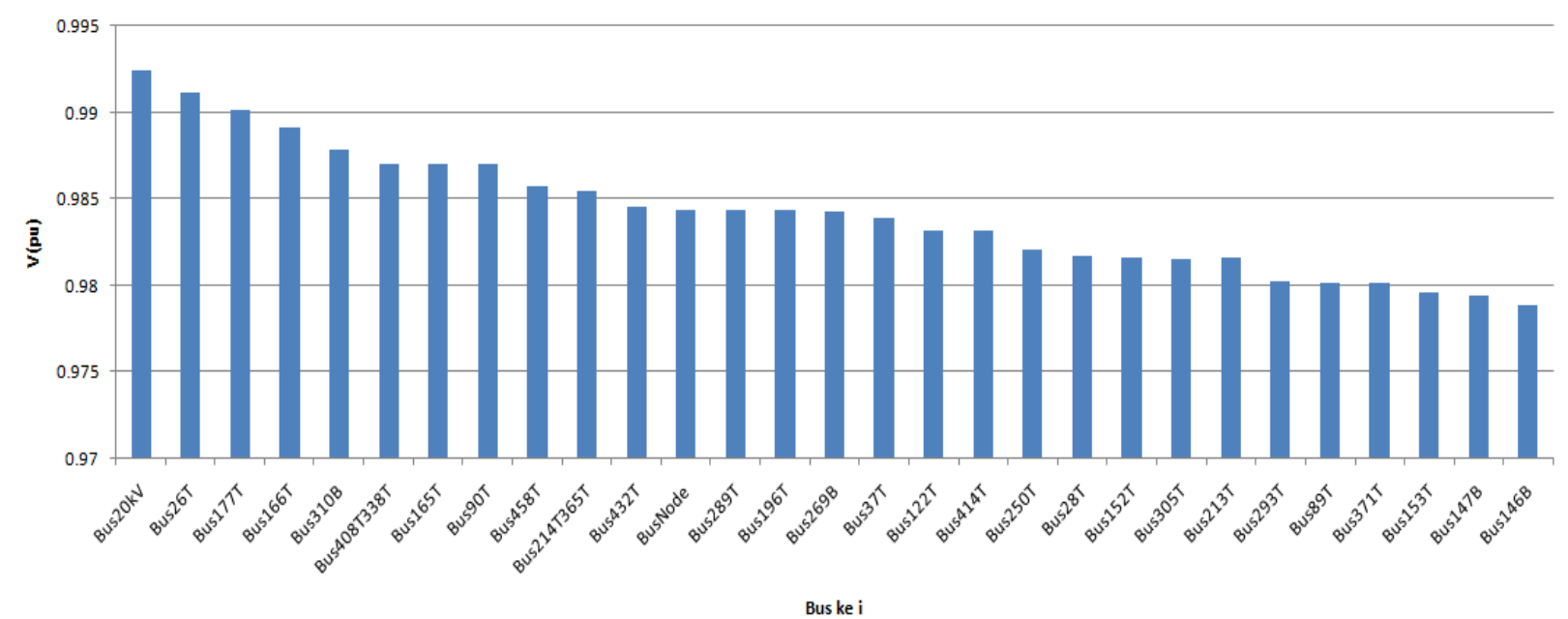

Gambar 4. Profil tegangan sebelum penempatan pembangkit terbesar 
Pada Gambar 7 dapat dilihat nilai VSI semakin kecil jika penempatan DG semakin jauh dari sumber yang cenderung tegangan terendah pada saluran. Hal ini karena penempatan DG pada tegangan yang terendah dapat mengurangi pasokan daya dari GI. Kondisi ini berakibat pada performansi tegangan sistem secara keseluruhan menjadi lebih baik. Pada metode ini lokasi pemasangan DG yang didapat pada kondisi performansi tegangan yang terbaik adalah pada bus 146B karena pada bus ini nilai VSInya paling kecil. Berdasarkan hasil simulasi diperoleh kapasitas optimum untuk DG photovoltaic dan wind turbine seperti ditunjukkan pada Gambar 8.

Berdasarkan Gambar 6 dan 8, disimpulkan bahwa teknologi photovoltaic lebih baik dalam mengurangi rugi saluran dibandingkan dengan wind turbine. Hal ini disebabkan karena wind turbine bekerja seperti mesin induksi yang menyerap daya reaktif dan menghasilkan daya aktif. Dengan menyerap daya reaktif dalam sistem akan menyebabkan mengalirnya arus reaktif pada wind turbine sehingga arus yang mengalir tersebut menyebabkan rugi sepanjang saluran.

\section{LSF}

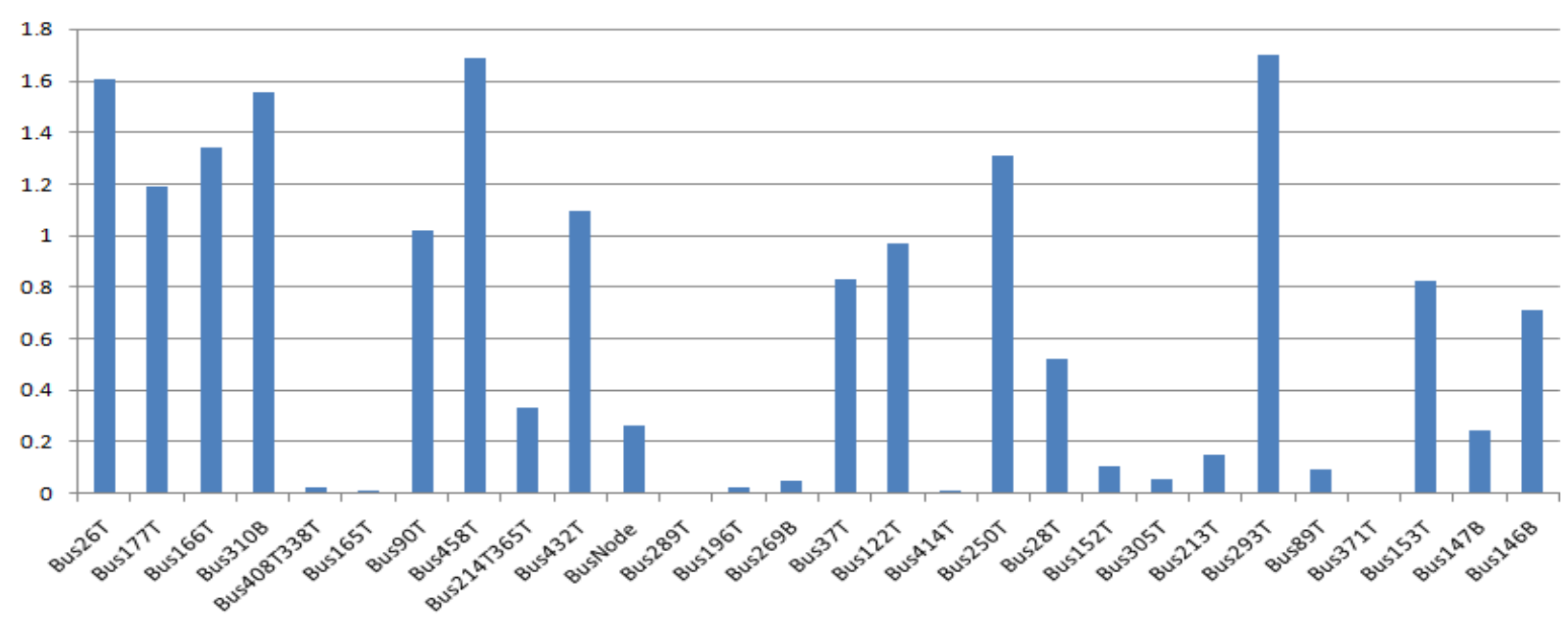

Gambar 5. Nilai sensitivitas rugi saluran pada setiap bus
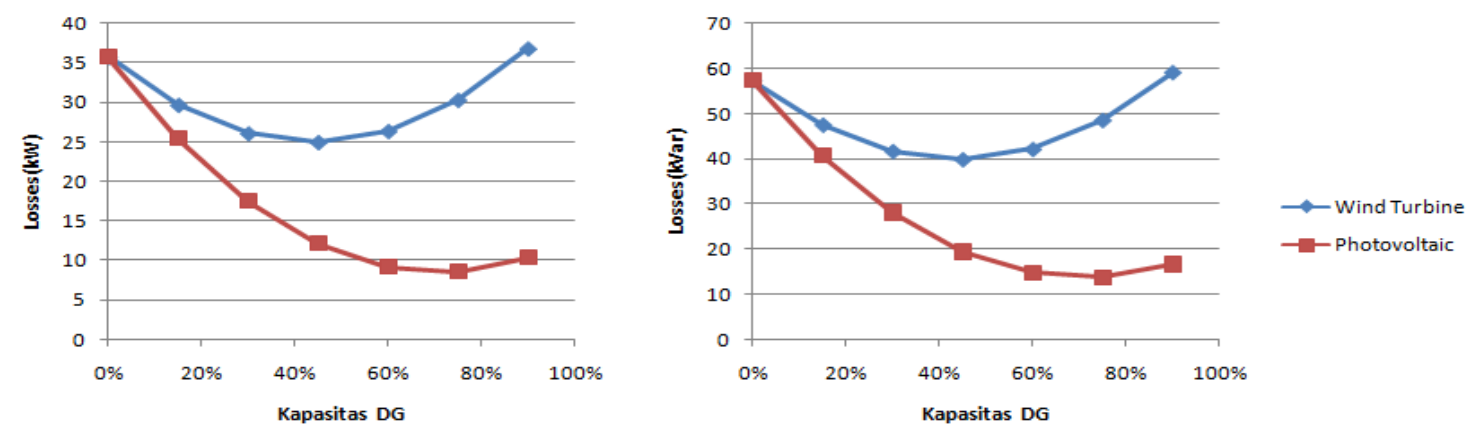

Gambar 6. Nilai rugi saluran terhadap kapasitas DG di bus 293T 


\subsection{Perbandingan setiap metode penempatan photovoltaic dengan trial and error}

Setelah diperoleh masing-masing nilai optimal rugi saluran pada kedua metode, nilai-nilai tersebut dibandingkan dengan nilai optimal yang diperoleh dengan mencobakan setiap variasi injeksi ke setiap bus. Nilai optimal ini diperoleh dengan cara mencoba setiap DG photovoltaic ke setiap bus dengan variasi injeksi $15 \%, 30 \%, 45 \%$, $60 \%, 75 \%$, dan $90 \%$. Hal ini membutuhkan waktu yang lama dibandingkan pencarian lokasi optimal dengan metode LSF dan VSI. Namun hasil yang diperoleh lebih tepat.

Pada Gambar 9 dapat diamati lokasi dimana rugi saluran yang paling optimal, yaitu pada bus 147B dengan penetrasi $75 \%$ dimana nilai rugi saluran yang diperoleh sebesar 8,159 kW. Nilainya cukup tipis jika dibandingkan dengan kedua metode diatas.

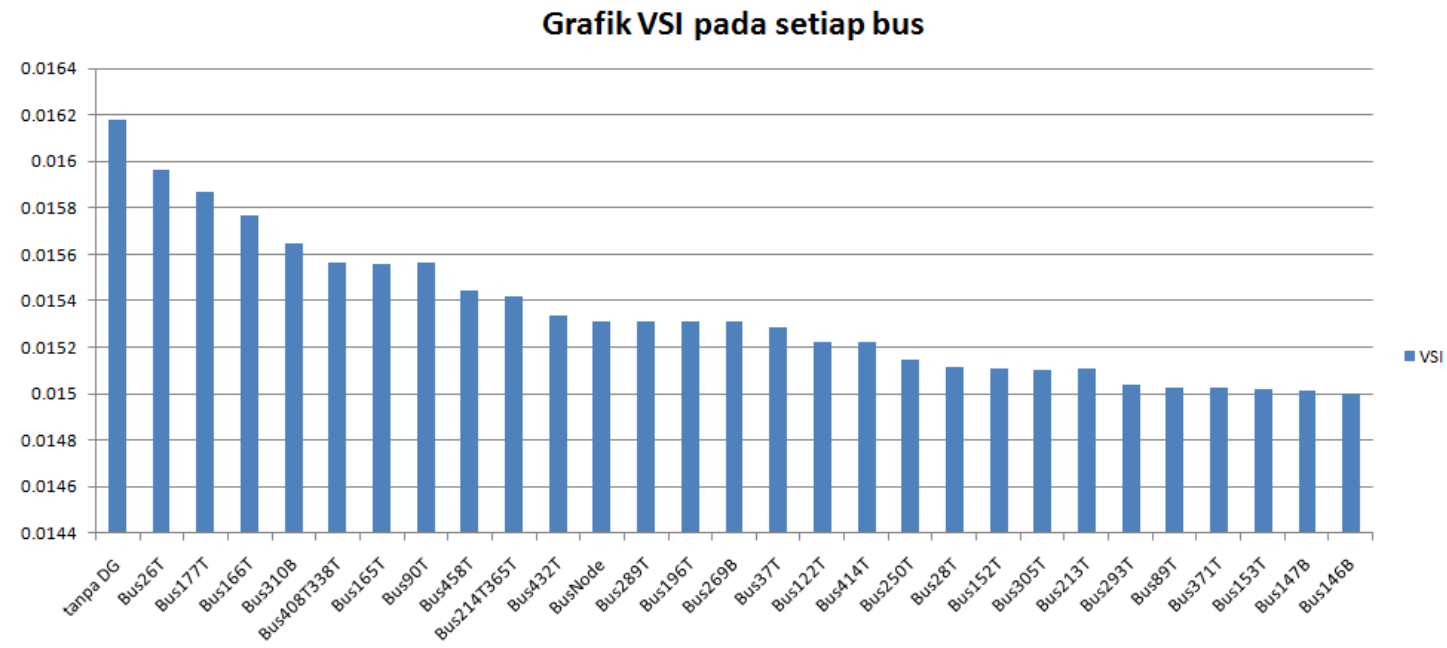

Gambar 7. Nilai sensitivitas tegangan indeks pada setiap bus
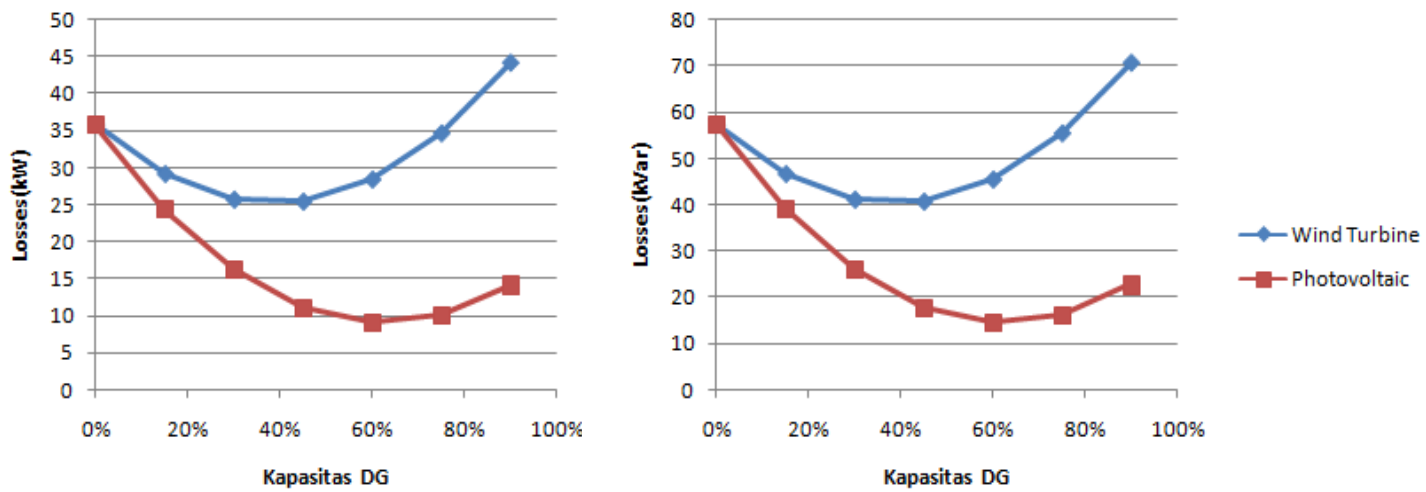

Gambar 8. Nilai rugi saluran terhadap kapasitas DG di bus 146B 
Dapat dilihat pada tabel 1, bahwa metode LSF lebih baik dibanding VSI dalam hal menentukan lokasi yang optimal terhadap rugi saluran. Namun dalam hal kenaikan tegangan metode VSI lebih baik karena penempatan dengan metode ini berdasarkan indeks sensitivitas tegangan pada jaringan. Sedangkan untuk profil tegangan pada setiap metode diatas dapat dilihat pada Gambar 10.

Tabel 1. Perbandingan setiap metode penempatan saat rugi saluran minimum

\begin{tabular}{|l|c|c|c|c|}
\hline Metoda pemilihan & Kondisi Awal & LSF & VSI & Trial and error \\
\hline Bus penempatan DG & - & $293 \mathrm{~T}$ & $146 \mathrm{~B}$ & $147 \mathrm{~B}$ \\
Kapasitas DG (\%) & 0 & 75 & 60 & 75 \\
Tegangan (p.u) & 0,9793 & 0,9871 & 0,9868 & 0,988 \\
Daya Beban(kW) & 4911,86 & 4973,9 & 4968,16 & 4979 \\
Losses(kW) & 35,792 & 8,588 & 9,118 & 8,159 \\
Daya Feeder(kW) & 4948 & 4983 & 4977 & 4987 \\
Daya Beban(kVar) & 2093 & 2118,8 & 2116,8 & 2119,9 \\
Losses(kVar) & 57,363 & 13,764 & 14,614 & 13,079 \\
Daya Feeder(kVar) & 2150 & 2133 & 2131 & 2133 \\
\hline
\end{tabular}

Pengaruh Penetrasi DG pada Setiap Bus terhadap Rugi Daya

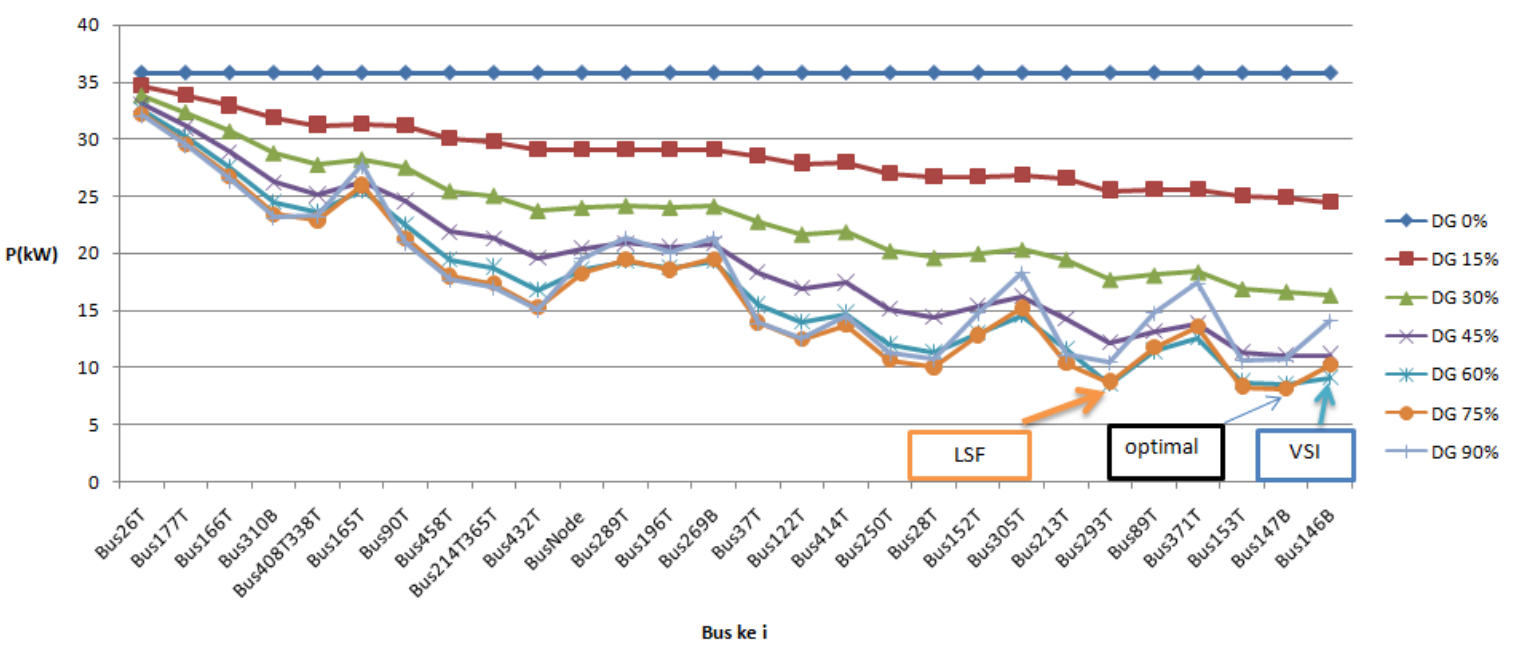

Gambar 9. Pengaruh kapasitas photovoltaic terhadap rugi saluran disetiap bus

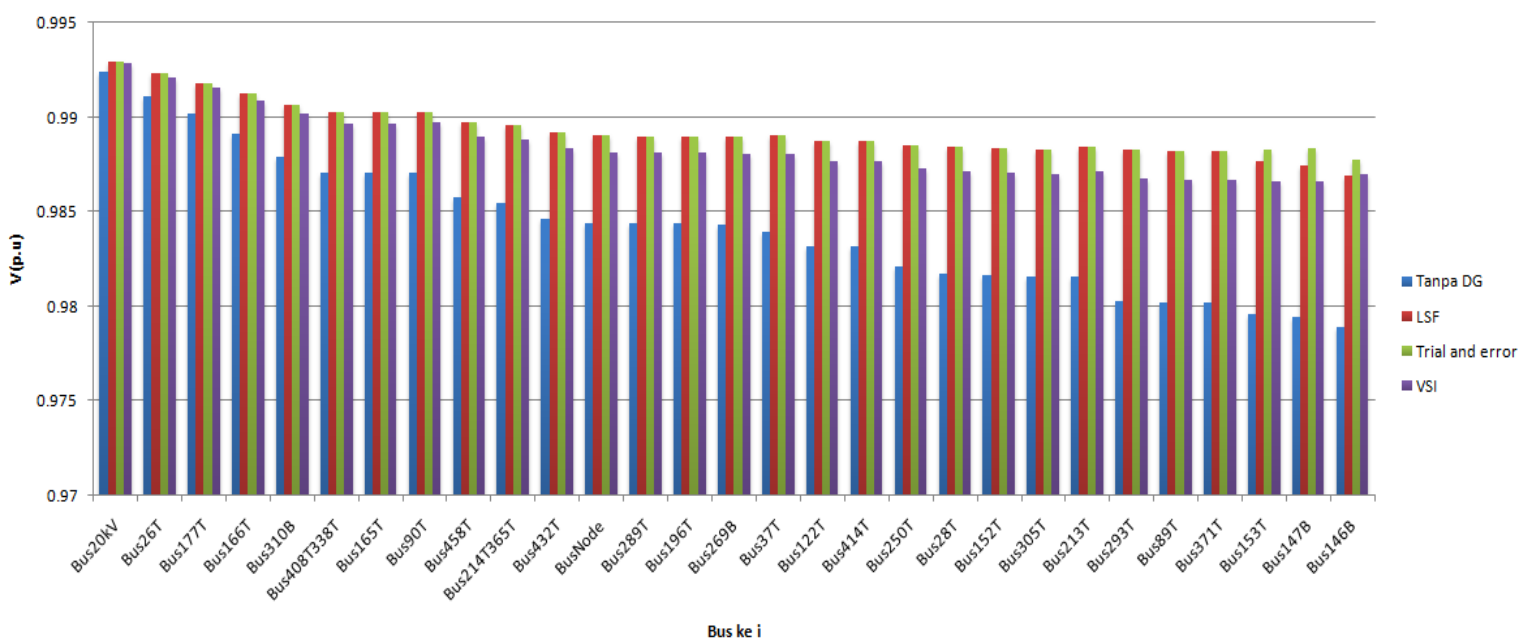

Gambar 10. Perbandingan profil tegangan saat rugi saluran minimum pada setiap metode 
Pada Gambar 10 dapat dilihat profil tegangan dengan metode LSF lebih baik dibandingkan metode VSI. Profil tegangan pada metode LSF mendekati nilai optimalnya. Namun semua metode, profil tegangannya masih batas normal, yaitu $\pm 5 \%$ atau dalam range $0.95-1.05$ p.u. sesuai dengan standar jatuh tegangan PLN.Hasil grafik diatas dapat dianalisa setelah optimasi penempatan dan kapasitas pembangkit tersebar profil tegangannya meningkat. Peningkatan tegangan diakibatkan setelah penempatan pembangkit tersebar pada jaringan. distribusi, arus yang mengalir dari gardu induk berkurang karena sebagian beban jaringan dipikul oleh DG sehingga tegangan jatuh (I.Z) berkurang.Berdasarkan hasil tersebut maka dipilih bus 147B dengan penetrasi sebesar $75 \%$ dari daya yang disuplai ke feeder Marapalam yang nilainya 4,069 MVA yang memberikan nilai rugi saluran paling minimal. Bus 147B pada pemodelan ETAP di feeder Marapalam berlokasi di PT. Ingasura di Jalan Gurun Laweh.

\subsection{Analisa rugi saluran dan profil tegangan setelah penempatan photovoltaic}

Hasil simulasi setelah optimasi penempatan pembangkit tersebar, total daya beban yang di suplai gardu induk adalah 0,918 MW dan 2,134 MVar sedangkan pembangkit tersebar sebesar 4,069 MVA dengan distribusi daya aktif dan reaktif beban pada penyulang Marapalam adalah 4,987 MW dan 2,134 MVar. Rugi saluran pada saluran sistem ini didapatkan sebesar $8,159 \mathrm{~kW}$ dan 13,079 kVar. Sedangkan tegangan terendah pada bus adalah 0.988 pu.

Rugi saluran yang didapat pada hasil simulasi jaringan distribusi setelah penambahan DG berkurang karena arus yang mengalir pada saluran kecil akibat sebagian beban telah di suplai oleh DG. Hal ini karena ketika DG dipasang dekat pada beban maka DG bertindak sebagai beban yang bernilai negatif yang menyebabkan beban pada sistem berkurang sehingga arus yang mengalir berkurang. Karena nilai arus berkurang mengalir pada saluran maka rugi saluran juga berkurang.

\section{Kesimpulan}

Rugi saluran yang diperoleh saat penetrasi photovoltaic lebih kecil dibandingkan dengan wind turbine. Sedangkan profil tegangan lebih baik saat penetrasi photovoltaic dibandingkan penambahan wind turbine.
Metode optimasi LSF dan VSI dapat digunakan untuk pencarian optimasi lokasi penempatan pembangkit tersebar lebih cepat dibandingkan pencarian pada setiap busnya yang memakan waktu lama. Pada penelitian ini rugi saluran aktif yang didapatkan pada kondisi optimal penempatan photovoltaic dengan metode LSF, VSI dan percobaan setiap bus berturut-turut adalah 8.588 $\mathrm{kW}, 9.118 \mathrm{~kW}$, dan $8.159 \mathrm{~kW}$. Penambahan DG photovoltaic pada jaringan distribusi mampu mengurangi rugi saluran hingga memperbaiki profil tegangan. Semakin besar kapasitas DG hingga nilai optimalnya semakin kecil rugi saluran, setelah melewati kapasitas optimalnya rugi saluran kembali meningkat. Sedangkan profil tegangan semakin baik jika DG photovoltaic yang di injeksikan juga semakin besar.

\section{Ucapan Terima Kasih}

Ucapkan terima kasih ditujukan kepada Jurusan Teknik Elektro Universitas Andalas, yang sudah memberikan dukungan dan bantuan finasial sesuai kontrak No. 091/UN.16.09.D/PL/2017, sehingga penelitian ini dapat dilakukan.

\section{Daftar Pustaka}

[1] Syafii, Syukri Yunus, dan Asrizal.” Analisa Pengaruh Integrasi Pembangkit Tersebar dalam sistem Komposit” JNTE, Vol: 3 No. 1 Maret 2014

[2] K. Bawan Elias. "Dampak pemasangan Distributed Generation terhadap rugi-rugi daya", Jurnal Ilmiah Foristek Vol.2, No.21, 2012.

[3] Hutauruk, Ir, Msc,. Transmisi Daya Listrik, Erlangga, Jakarta, 1985.

[4] Abdul Kadir et. al. , "Optimal placement and sizing of distributed generations in distribution systems for minimizing losses and THD", Turkish Journal of Electrical Engineering \& Computer Sciences, Vol. 21, pp. 2269-2282, 2013.

[5] Kamdar Krutak. "Optimal Capacity and Location Assessment of Natural Gas Fired Distributed Generation in Residential Areas". Thesis. Arizona State University, 2014.

[6] Gopiya Naik S. et. al., "Optimal Allocation of Distributed Generation in Distribution System for Loss Reduction", 2012 IACSIT Coimbatore Conferences", Vol. 28, 2012. 
[7] N. Singh, S. Ghost, dan K. Murari. "Optimal Sizing Placement of DG in a Radial Distribution Network using Sensitivity based Methods", International Electrical Engineering Journal, Vol. 6, No. 1, pp. 1727-1734, 2015.

[8] Fitrizawati et. al. "Pengaruh Pemasangan Distributed Generation terhadap Profil Tegangan pada Jaringan Distribusi”. Techno, ISSN 1410 - 8607. Vol. 13, No.1, April 2012.

[9] Abdul Kadir et. al. , "Optimal placement and sizing of distributed generations in distribution systems for minimizing losses and THD”, Turkish Journal of Electrical Engineering \& Computer Sciences, Vol. 21, pp. 2269-2282, 2013.

[10] Grainger, John J. dan William D. Stevenson, Jr..PowerSystem Analysis. Singapore: McGraw-Hill, Inc 1994.
[11] M.A. Mahmud et. al. "Analysis of Voltage Rise Effect on Distribution with Distributed Generation", Preprints of the $18^{\text {th }}$ IFAC World Congress Milano (Italy) August 28 September 2, 2011.

\section{Biodata Penulis}

Syukri Yunus, menyelesaikan S1 di Jurusan Teknik Elektro ITB tahun 1985 bidang teknik tenaga Listrik, S2 di Jurusan Ilmu Komputer UI tahun 1991. Sekarang bekerja sebagai staf Pengajar di Jurusan Teknik Elektro FT Unand.

Imbang Ismail, menyelesaikan S1 di Jurusan Teknik Elektro Unand tahun 2016 bidang teknik tenaga Listrik,. Sekarang bekerja sebagai karyawan PT. PLN. 